\title{
Front Matter: Volume 11585
}

, "Front Matter: Volume 11585," Proc. SPIE 11585, Biophotonics-Riga 2020, 1158501 (2 November 2020); doi: 10.1117/12.2586368

Event: Third International Conference Biophotonics Riga 2020, 2020, Riga, Latvia 


\section{PROCEEDINGS OF SPIE}

\section{Biophotonics-Riga 2020}

Janis Spigulis

Editor

24-25 August 2020

Riga, Latvia

Organized by

University of Latvia (Latvia)

Sponsored by

Latvian Council of Science (Latvia)

Published by

SPIE

Volume 11585 
The papers in this volume were part of the technical conference cited on the cover and title page. Papers were selected and subject to review by the editors and conference program committee. Some conference presentations may not be available for publication. Additional papers and presentation recordings may be available online in the SPIE Digital Library at SPIEDigitalLibrary.org.

The papers reflect the work and thoughts of the authors and are published herein as submitted. The publisher is not responsible for the validity of the information or for any outcomes resulting from reliance thereon.

Please use the following format to cite material from these proceedings:

Author(s), "Title of Paper," in Biophotonics—Riga 2020, edited by Janis Spigulis, Proceedings of SPIE Vol. 11585 (SPIE, Bellingham, WA, 2020) Seven-digit Article CID Number.

ISSN: 0277-786X

ISSN: 1996-756X (electronic)

ISBN: 9781510639997

ISBN: 9781510640009 (electronic)

Published by

SPIE

P.O. Box 10, Bellingham, Washington 98227-0010 USA

Telephone +1 3606763290 (Pacific Time) · Fax +1 3606471445

SPIE.org

Copyright (c) 2020, Society of Photo-Optical Instrumentation Engineers.

Copying of material in this book for internal or personal use, or for the internal or personal use of specific clients, beyond the fair use provisions granted by the U.S. Copyright Law is authorized by SPIE subject to payment of copying fees. The Transactional Reporting Service base fee for this volume is $\$ 21.00$ per article (or portion thereof), which should be paid directly to the Copyright Clearance Center (CCC), 222 Rosewood Drive, Danvers, MA 01923. Payment may also be made electronically through CCC Online at copyright.com. Other copying for republication, resale, advertising or promotion, or any form of systematic or multiple reproduction of any material in this book is prohibited except with permission in writing from the publisher. The CCC fee code is 0277 $786 \mathrm{X} / 20 / \$ 21.00$.

Printed in the United States of America by Curran Associates, Inc., under license from SPIE.

Publication of record for individual papers is online in the SPIE Digital Library.

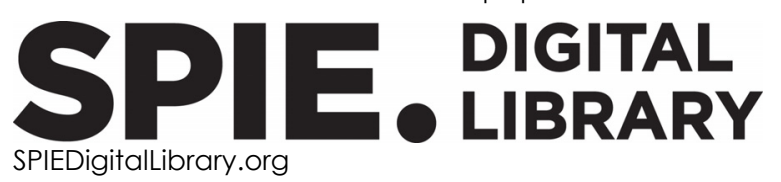

Paper Numbering: Proceedings of SPIE follow an e-First publication model. A unique citation identifier (CID) number is assigned to each article at the time of publication. Utilization of CIDs allows articles to be fully citable as soon as they are published online, and connects the same identifier to all online and print versions of the publication. SPIE uses a seven-digit CID article numbering system structured as follows:

- The first five digits correspond to the SPIE volume number.

- The last two digits indicate publication order within the volume using a Base 36 numbering system employing both numerals and letters. These two-number sets start with 00, 01, 02, 03, 04, 05, 06, 07, 08, 09, OA, OB ... 0Z, followed by 10-1Z, 20-2Z, etc. The CID Number appears on each page of the manuscript. 


\section{Contents}

INTRODUCTORY AND INVITED PAPERS

1158502 Biophotonics research in Riga: recent projects and results [11585-9]

1158503 Improved biomedical imaging over a wide spectral range from UV to THz towards multimodality (Invited Paper) [11585-20]

1158504 Multispectral fluorescence detection of pigmented cutaneous tumours (Invited Paper) [11585-11]

BIOMEDICAL TISSUE IMAGING

1158505 Remote photoplethysmography device with adaptive illumination for skin microcirculation assessment [11585-10]

1158506 Spectral imaging as a tool for the evaluation of skin cancer post-operative scars [11585-1]

1158507 Imaging photoplethysmography for evaluation of cutaneous sensory nerve fiber function [11585-4]

1158508 The assessment of gingivitis using remote photoplethysmography [11585-12]

1158509 Assessment of Candida albicans biofilm growth by laser speckle contrast imaging [11585-19]

\section{SKIN OPTICS AND SPECTROSCOPY}

$115850 \mathrm{~A}$ Objective noninvasive monitoring of laser tattoo removal in a human volunteer: a proof of principle study [11585-17]

11585 OB Study of As and TI high-frequency electrodeless lamps for Zeeman absorption spectroscopy [11585-3]

OPTICAL CLINICAL DIAGNOSTICS AND MONITORING

11585 OC Challenges of automatic processing of large amount of skin lesion multispectral data [11585-15]

11585 OD Deep learning model deploying on embedded skin cancer diagnostic device [11585-16] 
$11585 \mathrm{OE}$ Selection of erythema index and image sampling method for the objective erythema estimation in dogs with atopic dermatitis [11585-14]

11585 OF Photoplethysmographic waves and their detailed pulse interval distribution analysis on Poincare plots before and after the sauna exposures [1 1585-18]

11585 OG Acetone measurements in the exhaled air by the cavity ring-down spectrometry [11585-13]

$11585 \mathrm{OH} \quad$ Choice of photodetector characteristics for acousto-optic devices for bioelectric signals processing [11585-5]

$1158501 \quad$ Endoscopes for internal organs cancer diagnostics based on television and multispectral methods of image processing [11585-6]

$115850 \mathrm{~J}$ Optimization of information presentation process by multispectral processing systems of biological objects images [11585-7]

11585 OK Application of acousto-optic tunable filters in the devices of skin cancer diagnostics [11585-8] 